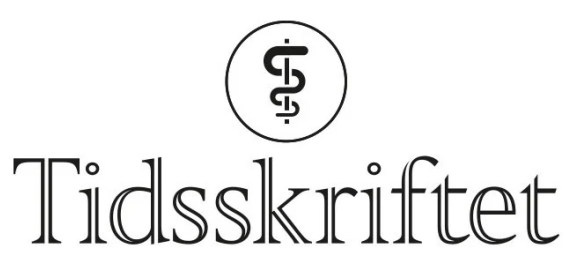

DEN NORSKE LEGEFORENING

\title{
Rettelse: Mer treffsikker fosterdiagnostikk
}

RETTELSE

IDA W. SØRENSEN

RAGNHILD GLAD

GUNNAR HOUGE

ANNE BLOMHOFF

MARTE G. HAUG

VIDAR M. STEEN

Tidsskr Nor Legeforen 2021; 141: 1338-40.

I Tidsskriftet nr. 14/2021, s. 1340 skal navnet på femteforfatter være Marte G. Haug.

Vi beklager feilen, den er rettet på nett.

Publisert: 20. oktober 2021. Tidsskr Nor Legeforen. DOI: 10.4045/tidsskr.21.0728

(C) Tidsskrift for Den norske legeforening 2023. Lastet ned fra tidsskriftet.no 26. april 2023. 